2

3

4

5

6

7

8

DR HANNA KATARIINA NUUTTILA (Orcid ID : 0000-0001-8032-1311)

Article type : Research Article

Handling editor: Nick Isaac

\title{
Estimating effective detection area of static passive acoustic data loggers from playback
}

\section{experiments with cetacean vocalisations}

Hanna Nuuttila ${ }^{1,2 *}$, Katharina Brundiers ${ }^{3}$, Michael Dähne ${ }^{3}$, Jens C. Koblitz ${ }^{3,4,5}$ Len Thomas ${ }^{6}$, Winnie Courtene-Jones ${ }^{7}$, Peter G.H. Evans ${ }^{8}$, John R. Turner ${ }^{2}$, Jim D. Bennell ${ }^{2}$ and Jan G. Hiddink $^{2}$

${ }^{1}$ SEACAMS Department of Biosciences, University of Swansea, Swansea, ${ }^{2}$ School of Ocean Sciences, University of Bangor, Menai Bridge, Anglesey, Wales, ${ }^{3}$ German Oceanographic Museum, Stralsund, Germany, ${ }^{4}$ Department of Biology, University of Konstanz, Konstanz, Germany, ${ }^{5}$ Department of Collective Behaviour, Max Planck Institute for Ornithology, Konstanz, Germany, ${ }^{6}$ Centre for Research into Ecological and Environmental Modelling, University of St Andrews, St Andrews, Scotland, ${ }^{7}$ The Scottish Association for Marine Science (SAMS), Oban, Argyll, Scotland, ${ }^{8}$ Sea Watch Foundation, Bull Bay, Anglesey, Wales

\section{Running title: Acoustic detection probability of SAM dataloggers}

* Correspondence author. Email: h.k.nuuttila@swansea.ac.uk, SEACAMS, Swansea University, Singleton Park, SA2 8PP 
1. Passive acoustic monitoring (PAM) is used for many vocal species. However, few studies have quantified the fraction of vocalisations captured, and how animal distance and sound source level affect detection probability. Quantifying the detection probability or effective detection area (EDA) of a recorder is a prerequisite for designing and implementing monitoring studies, and essential for estimating absolute density and abundance from PAM data.

2. We tested the detector performance of cetacean click loggers (C-PODs) using artificial and recorded harbour porpoise clicks played at a range of distances and source levels. Detection rate of individual clicks and click sequences (or click trains) was calculated. A Generalised Additive Model (GAM) was used to create a detection function and estimate the effective detection radius (EDR) and EDA for both types of signals.

3. Source level and distance from logger influenced the detection probability. Whilst differences between loggers were evident, detectability was influenced more by the deployment site than within-logger variability. Maximum distance for detecting real recorded porpoise clicks was $566 \mathrm{~m}$. Mean EDR for artificial signals with source level $176 \mathrm{~dB}$ re $1 \mu \mathrm{Pa} @ 1 \mathrm{~m}$ was 187 m., and for a recorded vocalisation with source level up to $182 \mathrm{~dB}$ re $1 \mu \mathrm{Pa}$ was $188 \mathrm{~m}$. For detections classified as harbour porpoise click sequences the mean EDR was $72 \mathrm{~m}$.

4. The analytical methods presented are a valid technique for estimating the EDA of any logger used in abundance estimates. We present a practical way to obtain data with a cetacean click logger, with the caveat that artificial playbacks cannot mimic real animal behaviour and are at best able to account for some of the variability in detections between sites, removing logger and propagation effects so that what remains is density and behavioural differences. If calibrated against real-world EDAs (e.g., from tagged animals) it is possible to estimate site-specific detection area and absolute density. We highlight the importance of accounting for both biological and environmental factors 
affecting vocalisations so that accurate estimates of detection area can be determined, and effective monitoring regimes implemented.

\section{Finnish Abstract}

1. Passiivista akustista seurantaa käytetään monien vokalisoivien lajien tutkimiseen. Harva tutkimus on määrittänyt äänitettyjä vokalisointeja tai tutkinut etäisyyden ja äänenvoimakkuuden vaikutusta akustisten laitteiden havaitsemisetäisyyteen (EDR), havaitsemisalueeseen (EDA) tai havaitsemistodennäköisyyteen. Nämä ovat kuitenkin edellytyksiä tehokkaiden kartoitustutkimusten suunnitteluun ja olleellisia tietoja lajien tiheyttä mitattaessa akustisilla laitteilla.

2. Me testasimme akustisten seurantalaitteiden (C-PODs) suorituskykyä jotka tallentavat pyöriäisten kaikuluotausäänisarjoja. Käytimme keinotekoisia sekä nauhoitettuja äänisarjoja joita toistettiin eri välimatkojen päästa ja eri lähdevoimakkuuksilla. Määrittelimme havaitsemisasteen sekä yksittaisille äänille etta äänisarjoille. Käytimme yleistettyä additivista mallia (GAM) luodaksemme funktiot havaitsemistodennäköisyydelle ja arvioimme laitteiden tehokkaimman havaitsemisalueen (EDA) molemmille eri signaaleille.

3. Sekä lähdevoimakkuus että välimatka vaikuttivat havaitsemistodennäköisyyteen. Vaikka yksilöllisillä laitteilla oli eroja, havaitsemistodennäköisyyteen vaikutti enemmän laitteen sijainti kuin laitteidenväliset erot.Suurin etäisyys josta pyöriäisvokalisaatio havaittiin oli 566 m. havaitsemisetäisyyden keskiarvo keinotekoisille signaaleille $176 \mathrm{~dB}$ re $1 \mu \mathrm{Pa} @$ 1m lähdevoimakkuudella oli 187 m., ja nauhoitetulle pyöriaisääntelyille lähdevoimakkuudella $182 \mathrm{~dB}$ re $1 \mu \mathrm{Pa}$ oli $188 \mathrm{~m}$. äänisarjojen havainnoille jotka laitteet automaattisesti luokitteli pyöriäisääniksi, keskiarvoinen havaitsemisetäisyys oli 72 m. 
4. Tässä esitetty laskennallinen menetelmä on pätevä tekniikka havaitsemisalueen arvoimiseen millä tahansa laitteella jonka tarkoituksena on lajien tiheyden laskeminen. Me esitämme käytännöllisen tavan hankkia dataa merinisäkkäiden äänisarjoista, vaikka huomautamme että keinotekoiset toistokokeet eivät voi imitoida oikeiden eläinten käyttäytymistä. Parhaimmillaan ne pystyvät ottamaan huomioon datan vaihtelevuuden laitteiden sijainnista johtuen, poistaen laitteidenväliset erot ja akustisen propagaation seuraukset, niin että tiheys (ja siihen vaikuttavat oikeiden eläinten käyttäytymisvaihtelut) voidaan määritellä. Jos akustiset laitteet voidaan lisäksi kalibroida todellisia havainnointietäisyyksiä vasten (esim. villeiltä, merkityiltä eläimiltä) on mahdollista arvioida aluekohtainen havainnointitodennäköisyys seka absoluuttinen eläintiheys. Korostamme biologisten sekä ympäristöllisten osatekijoiden vaikutusta ja painoarvoa eläinten vokalisaatiohin, jotta täsmällisiä ja todenpitäviä arviointeja lajitiheyteen voidaan määritellä ja tuloksia tuottavia seurantajärjestelmiä toteuttaa.

Key-words: C-POD, density estimation, detection function, effective detection radius, static passive acoustic monitoring, abundance. Word count: 7141

\section{Introduction}

Conservation and management of wildlife requires reliable estimates of animal abundance or density, traditionally achieved through visual counts or by (re-)capturing animals. Many animals, such as forest dwellers and diving marine species can be challenging to study due to inaccessibility of their habitats and limited availability for ground-based or sea surface-based observers. Visual monitoring methods are furthermore prone to inherent biases caused by temporal variability, observer ability and, particularly at sea, are limited to calm weather and 
good visibility. Visual surveys conducted in summer cannot predict abundance in other seasons, and if not conducted at frequent intervals have a low ability to detect long term trends in population status. Cryptic, but vocal species, including many monkeys, bats, birds, frogs and cetaceans are increasingly being monitored using passive acoustic methods. Various techniques have been developed for mobile (i.e. towed) acoustic methods for studying cetaceans (Barlow and Taylor, 2005; Akamatsu et al. 2008) but static devices pose a new set of challenges. Various automated acoustic devices to collect and analyse acoustic data can now detect and identify species and can be an efficient alternative to or complement existing visual sampling as they can be used in inaccessible areas, reduce disturbance caused by human presence, and maximise temporal coverage through a long-term sampling regime (Digby et al. 2013; Mellinger et al. 2007). In this paper, we present a technique for characterising the performance of an acoustic detector using playback experiments; although the technique is potentially applicable to terrestrial studies, our focus here is on cetaceans.

Effective abundance monitoring is crucial for species under threat from anthropogenic activities. One such species is the harbour porpoise (Phocoena phocoena, Linnaeus, 1758), which, although commonly sighted off the North East Atlantic coastline, is increasingly threatened by human activities; the Baltic subpopulation is listed as 'critically endangered' in the IUCN Red List (Hammond et al. 2008). The porpoise is difficult to monitor using visual techniques because of its small size and cryptic behaviour, but it lends itself well to acoustic studies because it emits stereotypical, narrow-band high frequency (NBHF) echolocation clicks and produces near continuous vocalisations apart from short rest periods (Linnenschmidt et al. 2013, Wright et al. 2017). Automated underwater click loggers such as C-PODs (Chelonia Ltd., Cornwall, UK) use waveform characterisation to identify clicks based on their intensity, bandwidth, frequency and duration. After retrieval of the devices, custom-written software then uses the recorded information to classify detected sounds into series, termed trains. These are further categorised 
based on their likely origin (boat sonar, dolphin, or porpoise) according to known characteristics of cetacean vocalisations. Click logger data are now widely used to evaluate presence and foraging behaviour of vocalising cetaceans in both coastal and offshore areas (Benke et al. 2014; Verfuß et al. 2007; Schaffeld et al. 2016; Simon et al. 2010); and assess disturbance from wind farms, shipping, fisheries and coastal development (Carstensen et al. 2006; Todd et al. 2009). They can also potentially be used to estimate animal density (Kyhn et al. 2012).

\section{Estimating density}

Several approaches have been developed to estimate animal density from stationary passive acoustic data (Marques et al. 2012); we introduce two here that are relevant to static loggers. In the first, the unit of analysis is an individual vocalisation, such as a cetacean click. Then,

$$
\widehat{D}=\frac{n(1-\hat{c})}{\hat{v} T \hat{r}} \quad(\text { Eqn. 1) }
$$

where $n$ is the number of detected vocalisations, $c$ is the proportion of those that are false positives (i.e., not from the target species), $v$ is the effective detection area (EDA, see below), $T$ is the total monitoring time summed over all detectors in the survey and $r$ is the average rate of sound production. The false positive rate, $c$, is estimated by inspecting a sample of the data under the assumption that a human analyst can accurately detect false positives. Sound production rate is best obtained from an auxiliary study where a sample of animals are fitted with acoustic recording tags and their vocalisation rate is measured; in practice, it is often obtained from studies undertaken in other times and places raising the possibility of bias. Here we focus on estimating EDA using recordings of cetacean echolocation, but the following equations can be applied to any animal that vocalises frequently. EDA is the area around a logger within which as many vocalisations are missed as are detected outside it; hence the EDA can be thought of as a measure of the area monitored by a logger. Acoustic detection is range-dependent, so one way to estimate EDA is by first estimating a detection function, $g(y)$ (Buckland et al. 2001), which 
describes the probability of detection as a function of horizonal range $y$ of the click from the logger. Assuming vocalisations are distributed randomly around the logger (or, more appropriately, that multiple loggers are used in the survey and that they are distributed randomly within the study area),

$$
v=2 \pi \int_{0}^{w} r g(y) d y \quad(\text { Eqn. } 2)
$$

where in theory $w=\infty$, but in practice some finite truncation distance is used where $g(y)$ is known to be 0. EDA is sometimes expressed in terms of the effective detection radius (EDR), $\rho$, i.e., the distance from the logger within which as many animals are missed as are detected outside it, where $\rho=\sqrt{v / \pi}$. Another related quantity is the detection probability, i.e., the average probability of detecting a sound within distance $w$ of the logger, $P_{a}=v / \pi w^{2}$.

In the second approach to density estimation (e.g., Kyhn et al. 2012), the monitoring time is divided into a sequence of short "snapshots" where animal movement is negligible. Echolocating animals click in a regular sequence (a "click train"), and hence it is typically possible to count the number of animals detected within a snapshot interval (i.e., the number of overlapping click trains). The unit of analysis in this approach is the total number of animal detections, summed over all snapshots. Density is estimated as

$$
\widehat{D}=\frac{n_{S}\left(1-\hat{c}_{S}\right)}{\hat{v}_{S} T_{S} \hat{r}_{S}} \quad(\text { Eqn. 3) }
$$

where $n_{S}$ is the number of animals detected, $c_{S}$ is the probability of a false positive animal detection, $v_{s}$ is the EDA for a vocalizing animal over the snapshot interval, $T_{s}$ is the total number of snapshots (summed over all sensors) and $r_{s}$ is the probability of an animal vocalizing at least once during a snapshot interval. A variant of this method can deal with the situation where animals are in groups, and multiple animals can be detected within a single snapshot (see Kyhn et al. 2012). 
In both the above formulations, a critical step is estimation of the detection function, $g(y)$, and hence the EDA. The most reliable way to do this is to collect auxiliary information from wildswimming animals within the study area during the time of the survey. In some cases, it may be possible to track a sample of animals in the vicinity of the loggers, for example by fitting them with acoustic- and location-sensing tags (e.g., Marques et al. 2009) or by observing them from a vantage point (e.g., Kyhn et al. 2012). However, tagging studies are logistically infeasible in many situations, and vantage points occur in limited locations and are only useful for species with short dive intervals.

Here, we present an alternative approach, based on playback of artificial cetacean clicks or real recordings. This has the advantage of being feasible for use in many cases at all sampling locations, and potentially at multiple times during the survey period. All acoustic studies should account for imperfect detectability, inherent in any detector and various factors affect the detection probability of cetaceans with acoustic dataloggers. In a marine environment, playbacks can account for some of these factors, such as distance, water temperature, background noise, salinity and substrate which can cause variation in sound propagation, or lead to transmission loss, absorption into sediment and potential shadowing from physical objects (Au 1993; Au \& Hastings 2008; DeRuiter et al. 2010; Zimmer 2011). However, a playback experiment cannot readily account for factors related to animal behaviour and activity state such as vocalisation rate, intensity and frequency of emitted sounds, direction of movement and orientation in the water column (Nuuttila et al. 2013), which must be borne in mind when interpreting results from such experiments. The first objective was to assess the performance of the hardware detection via the data logger's hydrophone in detecting playbacks of porpoise click-like artificial signals. The second objective was to examine the performance of the click train classification and species identification software by playing a recorded porpoise vocalisation sequence to the logger and calculating the detection rate for the clicks detected but also for click sequences identified by the 
algorithm (i.e., the snapshot method). The equations presented above can be adapted to other vocal species and acoustic instruments, both click loggers and full bandwidth recorders while the practical experiment presents a crucial step towards estimating cetacean abundance based on stationary acoustic monitoring of echolocation clicks.

\section{Materials and methods}

\section{C-POD calibration}

The frequency response of the C-POD hydrophone was $-208 \mathrm{~dB}$ re $1 \mathrm{~V} / \mathrm{uPa}$ at $130 \mathrm{kHz}$. Each logger was calibrated in a tank at the German Oceanographic Museum. This consisted of ensonifying each C-POD with a $130 \mathrm{kHz}$ artificially-created click signal at decreasing sound source levels and determining the sound pressure level threshold at four different positions around the C-POD where $50 \%$ of the transmitted signal was received by each POD. The average threshold level over the four positions was then used as the calibration sensitivity, which varied from $111 \mathrm{~dB}$ to $119 \mathrm{~dB}$ re $1 \mu \mathrm{Pa}$ peak-to-peak (pp) across the C-PODs used in the study. Details on methodology can be found in Dähne et al. (2013).

\section{C-POD deployment}

Fifteen calibrated loggers were deployed off New Quay, Wales, moored in five stations of three loggers each in a triangular formation, at depths of 13-20 m of water, $1.5 \mathrm{~m}$ above the seabed and approximately 50-75 m apart (Figure 1). All the playbacks were conducted in sea states two or less, to ensure stability of the recording set up and the accuracy of the distance measurements. A side-scan sonar survey of the area was conducted prior to the study, revealing a generally even, sandy bottom substrate. 
224 All the playbacks were conducted from a small inflatable boat drifting, with engine off, across the experimental area. An artificial click signal was used to create a repeatable signal where the source level could be manipulated to cover the intensity range of real harbour porpoise vocalisations. The signal consisted of 15 cycles of $130 \mathrm{kHz}$ frequency, generated via National Instruments Corporation Ltd (UK) 6356 usb-box and played back using National Instruments Labview software and an omni-directional transducer (Reson TC4033, Teledyne RESON A/S, Denmark, with a projective sensitivity of $137 \mathrm{~dB}$ pp re $1 \mu \mathrm{Pa} / \mathrm{V}$ for $130 \mathrm{kHz}$ signal. The signal was played back at different source levels (see below) and distances from 0-800 $\mathrm{m}$ from the CPODs, to assess the effect of varying intensity on detection probability. Due to the drift of the boat, the playbacks were conducted from a total of 744 different distances measured using the boat's GPS. The omni-directional transducer meant that the sound would travel to all directions resulting in expected detections across all C-PODs at varying distances.

The signals were fed through an amplifier (A-301, A.A. Lab Systems Ltd., gain 26 dB), which drove the transducer suspended from the boat at $2 \mathrm{~m}$ below the water surface. The playback consisted of four separate sequences. Each sequence contained eleven blocks of ten clicks (90 ms duration with $60 \mathrm{~ms}$ pause between each block); each block had different source levels (SL), decreasing in $3 \mathrm{~dB}$ steps over a range of $30 \mathrm{~dB}$ from $176 \mathrm{~dB}$ pp re $1 \mu \mathrm{Pa} / \mathrm{V} @ 1 \mathrm{~m}$ to $149 \mathrm{~dB} p$ re $1 \mu \mathrm{Pa} / \mathrm{V} @ 1 \mathrm{~m}$ (Figure $\mathrm{S} 1$, online supplement). Initially playbacks were conducted at higher source levels (up to $184 \mathrm{~dB}$ re $1 \mu \mathrm{Pa} / \mathrm{V} @ 1 \mathrm{~m}$ ) but $176 \mathrm{~dB}$ re $1 \mu \mathrm{Pa} / \mathrm{V} @ 1 \mathrm{~m}$ represented the maximum source level that could be produced with the used equipment without creating distorted waveforms.

\section{Playback with recorded porpoise vocalisations}


To assess the detection probability of actual harbour porpoise vocalisations, and the performance of the click train detection algorithm, echolocation clicks were recorded from captive porpoises at Fjord \& Bælt Center, Denmark, and compiled into an $18 \mathrm{~s}$ long sequence. The recording included clicks of varying amplitude and frequency ranges, with source levels between 130 and $182 \mathrm{~dB}$ re $1 \mu \mathrm{Pa}$, representing some of the known variability in click rate and source level of real porpoise vocalisations (See signal waveform in Figure S2, online supplement).

The recording was played using a similar setup as above but without an amplifier and through a calibrated directional transducer, a Reson TC2130, resonant at $104 \mathrm{kHz}$, with a usable transmitting band between $100-200 \mathrm{kHz}$, and a projection directionality of $12.3-16.9^{\circ}$ for a signal between $100-150 \mathrm{kHz}$, which is similar to a porpoise beam at $13^{\circ}$ at $130 \mathrm{kHz}$ (Koblitz et al. 2012). The playbacks were played from 590 different distances ranging from 0 to $640 \mathrm{~m}$ from the C-PODs with an additional gain of $20 \mathrm{~dB}$ generated through the computer, resulting in a maximum source level of $182 \mathrm{~dB}$ re $1 \mu \mathrm{Pa} / \mathrm{V} @ 1 \mathrm{~m}$. The directional transducer, which has a narrow beam was used to replicate a real porpoise to imitate the directionality and beam width of the animal. During playbacks it was continuously rotated from side to side horizontally in an arc movement of a porpoise head. The speed of rotational arc was not measured; it was based on subjectively determined observations of animals.

The distance between the playback vessel and each of the C-PODs was determined from GPS latitude and longitude coordinates using the spherical law of cosines as follows:

$$
y=\cos ^{-1}\left(\sin \left(\text { lat }_{1}\right) \sin \left(\text { lat }_{2}\right)+\cos \left(\text { lat }_{1}\right) \cos \left(\text { lat }_{2}\right) \cos \left(\text { long }_{2}-\operatorname{long}_{1}\right)\right) R
$$

271 where the position of the boat was defined as $l a t_{1}$ and $\operatorname{long}_{1}$, the position of the C-POD was defined as $l_{a t}$ and $l^{\circ} g_{2}$, and $\mathrm{R}$ was the mean radius of the earth $(6371 \mathrm{~km})$. 
275 The data were visually inspected using C-POD software v.2.026 (Chelonia, 2012) to assess

276 which playbacks were detected by the logger. For each artificial sequence, the C-POD raw click

277 files (CP1 files) were examined, and the number of clicks from each series and each block was counted. For the recorded porpoise click sequence, only those playbacks with a clear recording of the whole or part of the identifiable sequence were considered as detected. The resulting data was divided into three datasets, each analysed separately to assess the performance of the CPOD's KERNO train classification algorithmin identifying the playback sequence as of porpoise origin: 1) detections of playback sequence in raw click files (called CP1 files by the C-POD programme), 2) detections of trains (CP3 files), and 3) detections of porpoise trains (CP3 files).

To estimate the detection function for the artificial signal, the detected clicks were analysed using a Generalized Additive Mixed Model (GAMM), implemented via the gam function in the mgcv package in R (Wood 2006; 2011), with binomial error structure, logit link function and maximum likelihood (ML) parameter estimation. 'Detected' (1) or 'not detected' (0) was the binary response variable, with distance, source level, sensitivity, station and playback ID used as potential explanatory variables (on the logit scale). The numerical variables distance, source level and sensitivity were modelled using smooths (specifically, thin plate regression splines, with degree of smoothness selected by generalized cross validation). Playback ID and station were included as random effects, as each playback generated trials on each of the three C-PODs at a station, making the responses potentially non-independent. All potential main-effects models were fitted and the model with lowest Akaike Information Criterion (AIC) value was selected for inference (Burnham and Anderson, 1998). Models involving interactions were not considered. 
297 (conditioning on the selected model), treating each playback as the unit for resampling with 1000

298 bootstrap replicates.

299

300

The selected model was then used to estimate click detection probability as a function of distance

and the other selected variables; EDR was also calculated, by integrating out distance (Eqn. 2).

302

The statistical analysis was identical for the recorded porpoise sequence, with the omission of source level as explanatory variable.

304

305

\section{Results}

Playbacks with artificial porpoise clicks

307

Overall, 343 artificial playback sequences of 11 blocks of 10 clicks each were transmitted across the 15 C-PODs. This resulted in over 16000 recorded playback blocks that were visually assessed.

The model with lowest AIC values included all five explanatory variables (distance from data logger, source level, sensitivity, station and the random effect of playback; see Table S1 in the online supplement). The model explained $73.7 \%$ of the deviance in the dataset. As expected, there was a strong negative effect of increasing distance and lower source level of the playback on detection probability, but also a significant effect of sensitivity (Figure 2). The detection probability fell sharply between 100 and $300 \mathrm{~m}$ distance from the data logger. The effect of source level on detection probability increased sharply for clicks over $160 \mathrm{~dB} p \mathrm{pp}$ re $1 \mu \mathrm{Pa} / \mathrm{V} @ 1$ $\mathrm{m}$ for all C-PODs.

\section{$* *$ Figure $2 * *$}

The calculated EDR for artificial clicks with a source level of $176 \mathrm{~dB}$ re $1 \mu \mathrm{Pa}$ m varied from 225 to $148 \mathrm{~m}$, with a mean of $186 \mathrm{~m}$ (95\% CI: 173-200) averaging across the other explanatory variables and a mean EDA of $0.111 \mathrm{~km}^{2}$ averaging across all loggers. Lower source levels 
drastically decreased the EDR and detection area, with notable differences between C-PODs and sites (Figures 3, 4 and S3, online supplement). Results of GAMM-model (Table S1) showed a strong negative correlation with distance and decreasing source level and to a lesser degree with sensitivity. The EDR values with 95\% CI and CV for each C-POD for different source levels are listed in the online supplement in Table S2.

$$
\text { **Figure } 3 * *
$$

\section{Playbacks with recorded porpoise clicks}

The recorded porpoise sequence was played back 184 times across the data loggers producing 715 captured sequences across distances up to $640 \mathrm{~m}$ from the loggers. A total of 12 loggers out of the 15 deployed recorded usable data for this part of the experiment; data from station five was excluded from the analysis due to some unexplained discrepancies in recordings, some of which may have been due to mistakes in time stamping the recordings and erroneous start times of the devices. Consequently, only 409 of the captured sequences were usable for analysis.

For all three datasets (raw click files, (CP1 files); detections of trains (CP3 files) and detections of porpoise trains (CP3 files), GAMM with lowest AIC values included station, distance, sensitivity and the random effect for playback, although for the raw click data (CP1 files) and the train detection files, sensitivity was not a significant variable at the $\mathrm{P}=0.05$ level (Table S3 and Figure S5, online supplement). Station and distance were the most influential variables according to AIC scores. The models explained between $40 \%$ and $55 \%$ of the deviance in the datasets, notably less than the models for the artificial playbacks. Lowest detection probabilities for click data (CP1) were recorded for C-PODs 1A, 1C, 2A and 2B. High detection probability of clicks did not always correspond to high detection of classified porpoise trains (Figure S5 and S6, online supplement). 
The calculated mean EDR across all C-PODs for raw click data from the recorded signal was $188 \mathrm{~m}$ (95\% CI: 135-241). For the part of the signal that the algorithm recognised as click train sequence, the mean EDR was 116 m (95\% CI: 80-152) and for detected signal that was classified as porpoise train, the mean EDR was $72 \mathrm{~m}$ (95\% CI: 52-92) (Figure 4). The mean EDR values for the click data with $95 \mathrm{CI}$ and $\mathrm{CV}$ for each C-POD are listed in the online supplement Table S4. The EDA using the clicks detected from the raw click files (CP1) was $0.111 \mathrm{~km}^{2}$. When examining only those clicks that were correctly assigned as harbour porpoise trains by the classification algorithm, the effective area was reduced to $0.016 \mathrm{~km}^{2}$. The mean difference in EDR from detected clicks to correctly detected species was 105 m (95\% CI: 66-144).

$$
* * \text { Figure } 4 * *
$$

\section{Maximum detection distances}

Maximum detection distances where acoustic detections were still made depended on the source levels of the emitted signals. The maximum artificial click source level emitted without distortion was $176 \mathrm{~dB}$ re $1 \mu \mathrm{Pa} @ 1 \mathrm{~m}$. Our observed maximum detection distance for this source level was 545 m (recorded with C-POD 3B) and a mean detection distance was $402 \mathrm{~m}$ (95\% CI: $371-429)$.

The maximum detection distance for the recorded porpoise sequence was $566 \mathrm{~m}$ (C-POD 4C) and the mean maximum distance for all the C-PODs was 248 m (95\% CI: 181-316).

\section{Discussion}

Acoustic recorders are now commonly used, and they have the potential of estimating animal abundance. This is particularly important in the context of small cetaceans where click loggers are widely available, easy to use and provide cost effective way for long-term monitoring. Understanding the distance at which animals are detected and how source level and sensitivity affects their detectability is crucial for quantifying the species' area use. Accurate estimates of 
EDA are essential for density estimation using such devices. As far as we are aware, this is the

375 first published study to attempt the estimation of the detection probability and calculation of EDA for C-PODs, or any other static, single hydrophone click detector for high frequency odontocetes, using both artificial and recorded real cetacean clicks. Note however, that playback experiments cannot incorporate animal behavioural variability and thus cannot produce accurate estimates of detection probability. Although it is possible that some unavoidable multipath reflections were contained in the playback signal, those reflections should not have interfered with our analysis since multipath would have been very low in amplitude and therefore would not have trigger the detection threshold of the C-POD at longer distances. In very short ranges multipath reflections can be recorded as individual clicks of which only the first (direct path) was used for our calculations. As such, the use of an artificial click sequence allowed us to assess the evaluate the performance of the classification algorithm for one type of standardized sequence with some measure of potential variability exhibited by the porpoise.

As expected, the detection probability and the EDR decreased with increasing distance from data logger and the decreasing source level of the artificial signal. For porpoise-like sounds, no detections were made beyond $545 \mathrm{~m}$ from the logger, and signals below $153 \mathrm{~dB}$ pp re $1 \mu \mathrm{Pa} / \mathrm{V}$ at $1 \mathrm{~m}$ had less than 0.2 probability of being detected even at distances of less than $50 \mathrm{~m}$. The most here was at the edge of the performance capability of the transducer and may have caused slight distortion to the signal. Further experiments with higher performance transducers are therefore recommended to evaluate higher source levels. 
Similarly, decreasing detection probability with distance was evident with the real porpoise click sequences, with nearly the same EDR of $188 \mathrm{~m}$ for the raw data. The real clicks had generally higher detection probability and were detected from further away than the artificial clicks, despite being played back using a directional transducer which was being rotated from side to side. The higher detectability of the recorded real porpoises was likely because the probability of artificial signal detection was estimated for a single click, whereas the probability of real porpoise signal detection was calculated for the entire $18 \mathrm{~s}$ long snapshot sequence, more easily detected because

of its duration but also because parts of the sequence were played at higher maximum source level than the artificial playbacks (182 dB re $1 \mu \mathrm{Pa} / \mathrm{V} @ 1 \mathrm{~m})$ and highlights the main difference between the two methods for density estimation discussed earlier. No published EDR values for porpoise clicks exist for C-PODs, but for T-PODs the reported mean EDR for wild porpoises for a comparable time window of $15 \mathrm{~s}$ was approximately $30 \mathrm{~m}$, varying slightly with T-POD type and sensitivity (Kyhn et al. 2012). Here, the mean EDR of C-PODs for detecting and identifying recorded porpoise clicks as porpoises was much improved in comparison to T-PODs at $72 \mathrm{~m}$, although it must be noted that Kyhn's results were obtained from real, wild animals using visual tracking and could have thus been influenced by more unknown variables.

The highest source level of the real recorded porpoise signal was at $182 \mathrm{~dB}$ re $1 \mu \mathrm{Pa} @ 1 \mathrm{~m}$, yielding a maximum detection distance of $566 \mathrm{~m}$. The mean maximum distance for all the CPODs was $248 \mathrm{~m}$ (95\% CI: 181-316), reflecting much reduced detection rates due to the directional transducer used, emulating more closely the real-life scenario of actual porpoise movement patterns and sonar beam-width.

\section{Click detection vs. train classification}


As expected, the detection probability decreased from detected clicks to classified trains, and again to correctly classified species (Figure 4). The challenge remains for the software developers to improve the train classification algorithm to match the click detection abilities of the device, increasing its EDA - for the real porpoise click sequence used here, this would be a five-fold increase from 0.02 to $0.1 \mathrm{~km}^{2}$. As C-PODs do not record full waveforms they depend heavily in train detection on click intervals and their respective sequences. Therefore, an improvement is limited by the number of clicks necessary for classification and the allowed number of false positives. Attempt to reduce false positives typically increases false negative detections, however, in density estimation, false positive detections are perfectly acceptable, providing the false positive rate is accurately determined at the temporal and spatial scale of the density estimates, hence the parameter $c$ in equation 1 .

\section{Differences between loggers, deployment sites and playbacks}

It is crucial to ensure that data loggers used are calibrated to similar sensitivity thresholds. CPODs used in this study had a range in detection sensitivities at received levels between 111 and $119 \mathrm{~dB}$ re $1 \mu \mathrm{Pa}$ pp which is higher than advertised by the manufacturer. The measured calibration sensitivity had only a slight effect on the models, but there were large differences between calculated EDRs for C-PODs throughout the experiment. These are likely due to a combination of factors including C-POD sensitivity, subtle differences between deployment sites such as unexpected boulders or troughs in the seabed or variation in the substrate type, the deployment depth (Sostres and Nuuttila, 2015), and most importantly the added variability of the transmitted signal, due to hydrophone directionality and the added movement by the operator mimicking the side-to-side movement of the porpoise head. 
450 The source levels used here were based on limited recordings of wild porpoises (Villadsgaard et

451

452

453

454

455

456

457

458

459

460

461

462

463

464

465

466

467

468

469

470

471

472

473

al. 2007), which may not reflect the real variation in source levels, likely to be affected by behavioural context and variation in habitat characteristics, such as ambient noise. Such variation has been demonstrated for the beluga whale (Delphinapterus leucas), adapting the source level and frequency of its echolocation clicks according to noise levels of its surroundings (Au et al. 1985). Kyhn et al. (2013) show that recorded source levels of harbour porpoises can vary drastically between 169 and $199 \mathrm{~dB}$ re $1 \mu \mathrm{Pa}$ m for Danish porpoises and 170 to $189 \mathrm{~dB}$ re $1 \mu \mathrm{Pa}$ $\mathrm{m}$ for porpoises from British Columbia resulting in a mean difference of $10 \mathrm{~dB}$ between the habitats. Furthermore, Villadsgaard et al. (2007) reported differences between porpoises in captivity and in the wild of $\sim 20 \mathrm{~dB}$ showing a habituation to the environment. Therefore, measurement of source levels in the area of concern is a prerequisite for estimating abundance from stationary acoustic data loggers.

Here, the maximum undistorted source level achieved was $182 \mathrm{~dB}$ pp re $1 \mu \mathrm{Pa} / \mathrm{V} @ 1 \mathrm{~m}$ for the recorded real porpoise signal, which is considerably less than the maximum recorded level of $205 \mathrm{~dB}$ re $1 \mu \mathrm{Pa} / \mathrm{V} @ 1 \mathrm{~m}$, and therefore the EDRs reported here will not represent the full detection range of wild porpoises. High source levels have been calculated for the most intense, "on-axis" clicks, whereas the loggers will detect both on and off axis clicks, and consequently clicks of varying source levels. Here we aimed to achieve this variation by swivelling the transducer from side to side and although we believe that these results represent at least some of the natural variability of porpoise click trains arriving at a C-POD, they still cannot accurately reflect the variation in natural vocalisation behaviour or in fact the actual position of the animals in the water column, depending on their behaviour and prey type targeted (Sostres and Nuuttila 2015). 
476 Here we provide a way to use playbacks to estimate an EDR and EDA, which could be repeated 477 at sites where monitoring studies require some estimate of a local detection probability for an

478 effective sampling regime. The challenge for this data logger is not detecting the clicks - as seen here, the C-POD detects porpoise clicks well. However, train classification and species identification necessarily require more information, and this consequently reduces the EDR. In areas of low animal density, with no other cetacean species present, it would be practical to use the raw click data or the train classification results, without species identification, improving the overall detection rate and enlarging the EDA. However, where there are several species present this approach is not workable and species classification is the most practical way of distinguishing species, regardless of the reduced EDR. Most importantly EDR and playback experiments provide means to quantify effort in stationary acoustic monitoring, not only applicable and necessary for large scale efforts in monitoring, but also for small scale studies such as analysing the impacts of anthropogenic activities on odontocetes.

To fully establish detection probabilities for cetaceans, we need to gain a thorough understanding of the effect of behaviour and group size on vocalisation rates (Nuuttila et al. 2013), including the portion of time the animals rest and spend silent, all of which can affect detectability (Wright et al. 2017). We can be relatively certain that porpoise vocalisation rates vary according to time of day (Todd et al. 2009, Schaffeld et al. 2016), increase during prey capture (DeRuiter et al. 2009; Verfuß et al. 2009), and decrease or are non-existent during rest periods (Linnenschmidt et al. 2013; Wright et al. 2017), and that source levels of their feeding buzzes are reduced making them less detectable than other clicks at similar ranges (DeRuiter et al. 2009). For many other cetacean species, we have only limited information on their vocalisation rates, and further research is required. 


\section{ACKNOWLEDGEMENTS}

We thank the Cardigan Bay Acoustic Tracking Study (C-CATS) volunteer team for their hard work during the field component of this study. We thank Magnus Wahlberg for the loan of the directional transducer, Martin Jabbusch, Nick Tregenza, Stacy de Ruiter, Harald Benke for helpful comments, and A. Hill and an anonymous reviewer for their constructive feedback. The study was funded by the Federal Ministry for the Environment, Nature conservation and Nuclear Safety of Germany (FKZ: 0325238), Bangor University and supported by SeaMôr Wildlife Tours.

\section{AUTHOR CONTRIBUTION STATEMENT}

HN, JK, KB, and LT conceived the ideas and designed methodology; HN, KB, WCJ, and JK collected the data; JB Assisted with collecting and analysing auxiliary information on study site; $\mathrm{HN}, \mathrm{KB}, \mathrm{WCJ}, \mathrm{MD}$ and LT analysed the data; HN, KB, MD and LT led the writing of the manuscript. All authors contributed critically to the drafts and gave final approval for publication.

\section{DATA ACCESSIBILITY}

Data used for this study are archived in the Swansea University Open Research Data site at Zenodo, https://zenodo.org/badge/DOI/10.5281/zenodo.1421093.svg.

\section{REFERENCES}

Akamatsu, T., Wang, D., Wang, K., Li, S., Dong, S, Zhao, X., Barlow J., Stewart, B.S., Richlen, M. (2008). Estimation of the detection probability for Yangtze finless porpoises (Neophocaena phocaenoides asiaeorientalis) with a passive acoustic method. The Journal of the Acoustical Society of America 123(6):4403-11. DOI: 10.1121/1.2912449

Au, W.W.L. (1993). The Sonar of Dolphins. Springer-Verlag, New York. 
Au, W.W.L., Carder, D.A., Penner, R.H. \& Scronce, B.L. (1985). Demonstration of adaptation in beluga whale echolocation signals. Journal of Acoustical Society of America, 77, 726-730.

Au, W.W.L. \& Hastings, M.C. (2008). Principles of Marine Bioacoustics. Springer Science and Business, New York.

Barlow, J., and Taylor, B.L. (2005). Estimates of sperm whale abundance in the northeastern temperate Pacific from a combined acoustic and visual survey. Marine Mammal Science 21:429445

Brundiers, K., Clausen, K.T., Tougaard, J., Kyhn, L.A., Sveegaard, S., Thomas, L., Teilmann, J., Benke, H. \& Koblitz, J.C. (2012). Acoustic detection functions of C-PODs: estimating probability of detecting harbour porpoise clicks using playback experiments. Presented at the Annual Conference of the European Cetacean Society, Galway, Ireland.

Benke, H., Bräger, S., Dähne, M., Gallus, A., Hansen, S., Honnef, C.G., Jabbusch, M., Koblitz, J.C., Krügel, K., Liebschner, A., Narberhaus, I., Verfuß, U.K. (2014). Baltic Sea harbour porpoise populations: status and conservation needs derived from recent survey results. Marine Ecology Progress Series: 495, 275-290 doi: 10.3354/meps10538

Buckland, S.T., Anderson, D.R., Burnham, K.P., Laake, J.L., Borchers, D.L. \& Thomas, L. (2001). Introduction to Distance Sampling: Estimating Abundance of Biological Populations. Oxford University Press, New York, 432 pages.

Burnham, K.P., Anderson, D. R.(1998) Model Selection and Multimodel InferenceA Practical Information-Theoretic Approach. 2nd edn. Springer-Verlag New York Berlin Heidelberg

Carstensen, J., Henriksen, O.D. \& Teilmann, J. (2006). Impacts of offshore wind farm construction on harbour porpoises: acoustic monitoring of echolocation activity using porpoise detectors (T-PODs). Marine Ecology Progress Series, 321, 295-308. 
Chelonia Ltd, (2012). Tone logging, Retrieved from

www.chelonia.co.uk/downloads/Tone\%20logging.ppt, date last viewed 10/08/12.

Dähne, M., Verfuß, U.K., Brandecker, A., Siebert, U. \& Benke, H. (2013) Methodology and results of calibration of tonal click detectors for small odontocetes (C-PODs) J. Acoust. Soc. Am. $1342514-22$

DeRuiter, S.L., Bahr, A., Blanchet, M.A., Hansen, S.F., Kristensen, J.H., Madsen, P.T., Tyack, P.L. \& Wahlberg, M. (2009). Acoustic behaviour of echolocating porpoises during prey capture. Journal of Experimental Biology, 212, 3100-3107.

DeRuiter, S., Hansen, M., Koopman, H.N., Westgate, A.J., Tyack, P.L. \& Madsen, P.T. (2010). Propagation of narrow-band-high-frequency clicks: Measured and modeled transmission loss of porpoise-like clicks in porpoise habitats. $127,560-567$.

Digby, A., Towsey, M., Bell, B.D. and Teal, P.D. (2013) A practical comparison of manual and autonomous methods for acoustic monitoring. Methods in Ecology and Evolution, 4, 675-683

Fisher, F.H. \& Simmons, V.P. (1977). Sound absorption in sea water. The Journal of the Acoustical Society of America, 62, 558-564.

Hammond, P.S., Bearzi, G., Bjorge, A., Fomey, K., Karczmarski, L., Kasuya, T., Perrin, W.F., Scott, M.D., Wang, J.Y., Wells, R.S. \& Wilson, B. (2008). Phocoena phocoena (Baltic Sea subpopulation). In: IUCN 2012. IUCN Red List of Threatened Species. Version 2012.1. <www.iucnredlist.org >. Accessed on 22 June 2012.

Katsanevakis, S., Weber, A., Pipitone, C. Leopold, M., Cronin, M., Scheidat, M. Doyle, T.K., Buhl-Mortensen, L., Buhl-Mortensen, P., D’Anna, G., de Boois, I.,Dalpadado, P., Damalas, D., Fiorentino, F., Garofalo, G. Giacalone, V.M., Hawley, K.L., Issaris, Y., Jansen, J., Knight, C.M, 
570 Knittweis, L., Kröncke, I., Mirto, S., Muxika, I., Reiss, H., Skjoldal, H.R., Vögel, S. (2012)

571 Monitoring marine populations and communities: methods dealing with imperfect detectability.

572 Aquatic Biology, 16: 31-52.

573 Koblitz, J.C., Wahlberg, M., Stilz, P., Madsen, P.T., Beedholm, K. \& Schnitzler, H.U. (2012).

574 Asymmetry and dynamics of a narrow sonar beam in an echolocating harbor porpoise. The

575 Journal of the Acoustical Society of America, 131, 2315-2324.

576 Kyhn, L.A., Tougaard, J., Thomas, L., Duve, L.R., Stenback, J., Amundin, M., Desportes, G. \& 577 Teilmann, J. (2012). From echolocation clicks to animal density-Acoustic sampling of harbor 578 porpoises with static data loggers. The Journal of the Acoustical Society of America, 131, 550579560.

580 Kyhn, L. A., Tougaard, J., Beedholm, K., Jensen, F. H., Ashe, E., Williams, R. \& Madsen P. T. 581 (2013). Clicking in a killer whale habitat: narrow-band, high-frequency biosonar clicks of 582 harbour porpoise (Phocoena phocoena) and Dall's porpoise (Phocoenoides dalli). PLoS ONE 583 8(5): e63763. doi.org/10.1371/journal.pone.0063763.

584 Linnenschmidt, M., Teilmann, J., Akamatsu, T., Dietz, R. \& Miller, L.A. (2013). Biosonar, dive, 585 and foraging activity of satellite tracked harbor porpoises (Phocoena phocoena). Marine 586 Mammal Science, 29(2), E77-E97. doi: 10.1111/j.1748-7692.2012.00592.x.

587 Marques, T.A., Thomas, L., Ward, J., DiMarzio, N. \& Tyack, P.L. (2009). Estimating cetacean 588 population density using fixed passive acoustic sensors: An example with Blainville's beaked 589 whales. The Journal of the Acoustical Society of America, 125, 1982-1994. 
Marques, T. A., Thomas, L., Martin, S. W., Mellinger, D. K., Ward, J.A., Moretti, D.J., Harris, D., Tyack, P.L. (2012). Estimating animal population density using passive acoustics. Biological reviews 88 (2): 287-309.

Mellinger, D.K., Stafford, K.M., Moore, S.E., Dziak, R.P. \& Matsumoto, H. (2007). An overview of fixed passive acoustic observation methods for cetaceans. Oceanography, 20, 3645.

Nuuttila, H., Thomas, L., Hiddink, J.G., Meier, R., Turner, J.R., Bennell, J.D., Tregenza, N.J.C. \& Evans, P.G.H. (2013). Acoustic detection probability of bottlenose dolphins, Tursiops truncatus, with static acoustic dataloggers in Cardigan Bay, Wales. The Journal of Acoustical Society of America, 134(3), Pt.2 2596-2609 doi: 10.1121/1.4816586.

Otani, S., Naito, Y., Kato, A. \& Kawamura, A. (2001). Oxygen consumption and swim speed of the harbor porpoise Phocoena phocoena. Fisheries Science, 67, 894-898.

Schaffeld T, Bräger S, Gallus A, Dähne M, Krügel K, Herrmann A, Jabbusch M, Ruf T, Verfuß UK, Benke H, Koblitz JC (2016) Diel and seasonal patterns in acoustic presence and foraging behaviour of free-ranging harbour porpoises Marine Ecology Progress Series 547, 257-272.

Simon, M., Nuuttila, H., Reyes-Zamudio, M.M., Ugarte, F., Verfub, U. \& Evans, P.G.H. (2010). Passive acoustic monitoring of bottlenose dolphin and harbour porpoise, in Cardigan Bay, Wales, with implications for habitat use and partitioning. Journal of the Marine Biological Association of the United Kingdom, 90, 1539-1545.

Sostres Alonso M, and Nuuttila HK (2015) Detection rates of wild harbour porpoises and bottlenose dolphins using static acoustic click loggers vary with depth. Bioacoustics 24(2). doi:10.1080/09524 622.2014.980319 
612 Stevenson, B. C., Borchers, D. L., Altwegg, R., Swift, R. J., Gillespie, D. M. and Measey, G. J. 613 (2015), A general framework for animal density estimation from acoustic detections across a 614 fixed microphone array. Methods Ecol Evol, 6: 38-48. doi:10.1111/2041-210X.12291

615 Todd, V.L.G., Pearse, W.D., Tregenza, N.C., Lepper, P.A. \& Todd, I.B. (2009). Diel

616 echolocation activity of harbour porpoises (Phocoena phocoena) around North Sea offshore gas 617 installations. ICES Journal of Marine Science: Journal du Conseil, 66, 734-745.

618 Verfuß, U.K., Honnef, C.G., Meding, A., Dähne, M., Mundry, R. \& Benke, H. (2007).

619 Geographical and seasonal variation of harbour porpoise (Phocoena phocoena) presence in the 620 German Baltic Sea revealed by passive acoustic monitoring. Journal of the Marine Biological 621 Association of the United Kingdom, 87, 165-176.

622

623 624 625 626 627 628 629 630 631

Verfuß, U.K., Miller, L.A., Pilz, P.K.D. \& Schnitzler, H.U. (2009). Echolocation by two foraging harbour porpoises (Phocoena phocoena). Journal of Experimental Biology, 212, 823834.

Villadsgaard, A., Wahlberg, M. \& Tougaard, J. (2007). Echolocation signals of wild harbour porpoises, Phocoena phocoena. The Journal of experimental biology, 210, 56-64.

Westgate, A.J., Head, A.J., Berggren, P., Koopman, H.N. \& Gaskin, D.E. (1995). Diving behaviour of harbour porpoises, Phocoena phocoena. Canadian Journal of Fisheries and Aquatic Sciences, 52, 1064-1073.

Wood, S.N. (2006). Generalized Additive Models: An Introduction with R. Chapman and Hall/CRC.

Wood, S.N. (2011). gamm4: Generalized additive mixed models using mgcv and lme4. R Packgae version 0.1-5. Httpp://CRAN.R-project.org/package=gamm4 
634 Wright, A.J., Akamatsu, T., Mouritsen, K.N., Sveegard, S., Dietz, R and Tielmann, J. (2017)

635 Silen porpoise: potential sleepin behaviout identified in wild harbour porpoises. Animal

636 Behaviour 133: 211-222

637 Zimmer, W.M.X. (2011). Passive Acoustic Monitoring of Cetaceans, 1st edn. Cambridge

638 University Press, Cambridge.

639

640 Figure and table legends

641

642

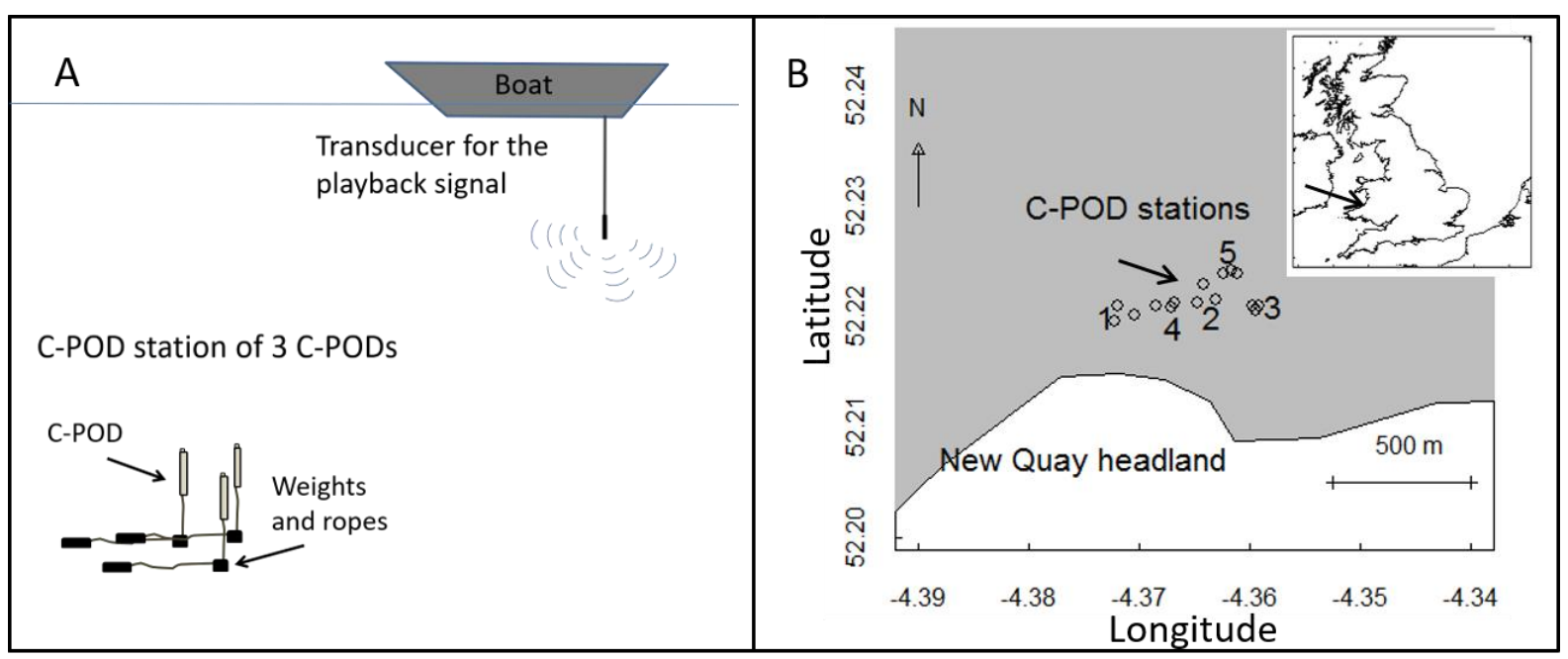

643 Figure 1. A diagram of a C-POD mooring set up for each station (A) and the map of the 644 deployment site of all the C-PODs (B). For each of the five station, three C-PODs were moored 645 on the sea bed and the playback transducer was suspended from the boat. 

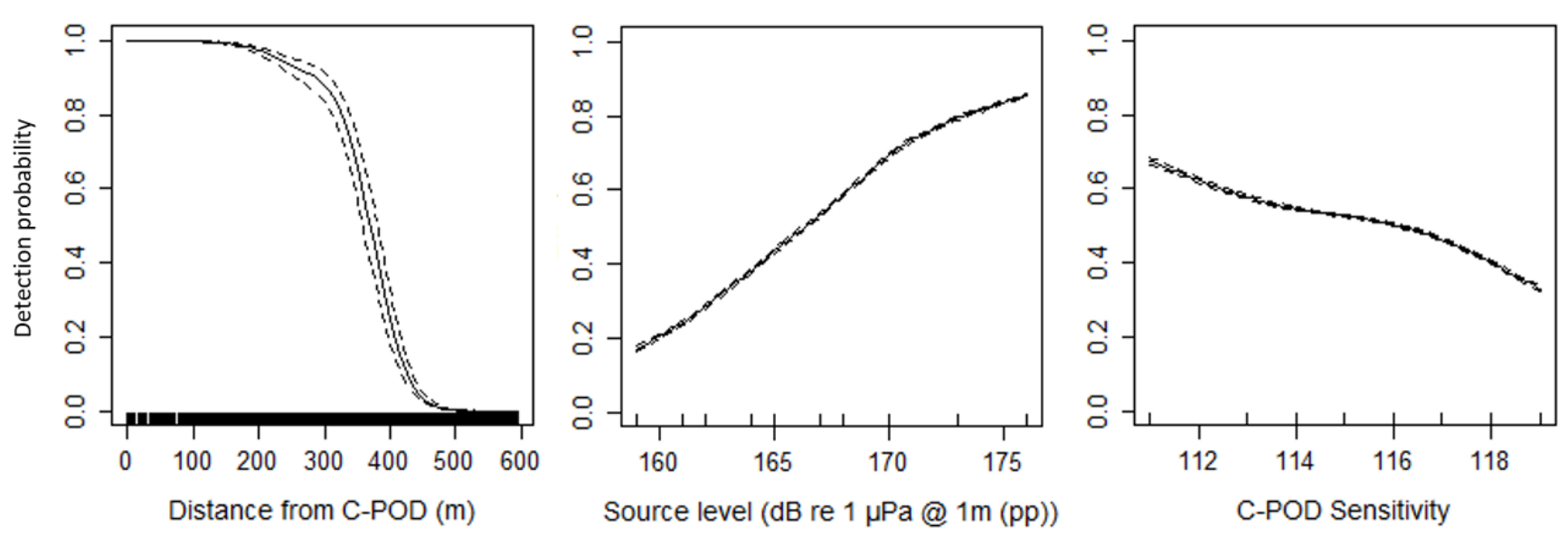

658

659

Figure 2. The effect of distance from C-POD, the signal source level and logger sensitivity on

660 the detection probability of artificial playback signal in the GAMM model, estimated at the mean 661 value of other covariates. Dashed lines indicate plus and minus two standard errors from the 662 estimates; $\mathrm{y}$-axis is transformed to the response variable scale, and the up-ticks on $\mathrm{x}$-axis show 663 the covariate values in the data.

664

665

666

667

668

669

670 

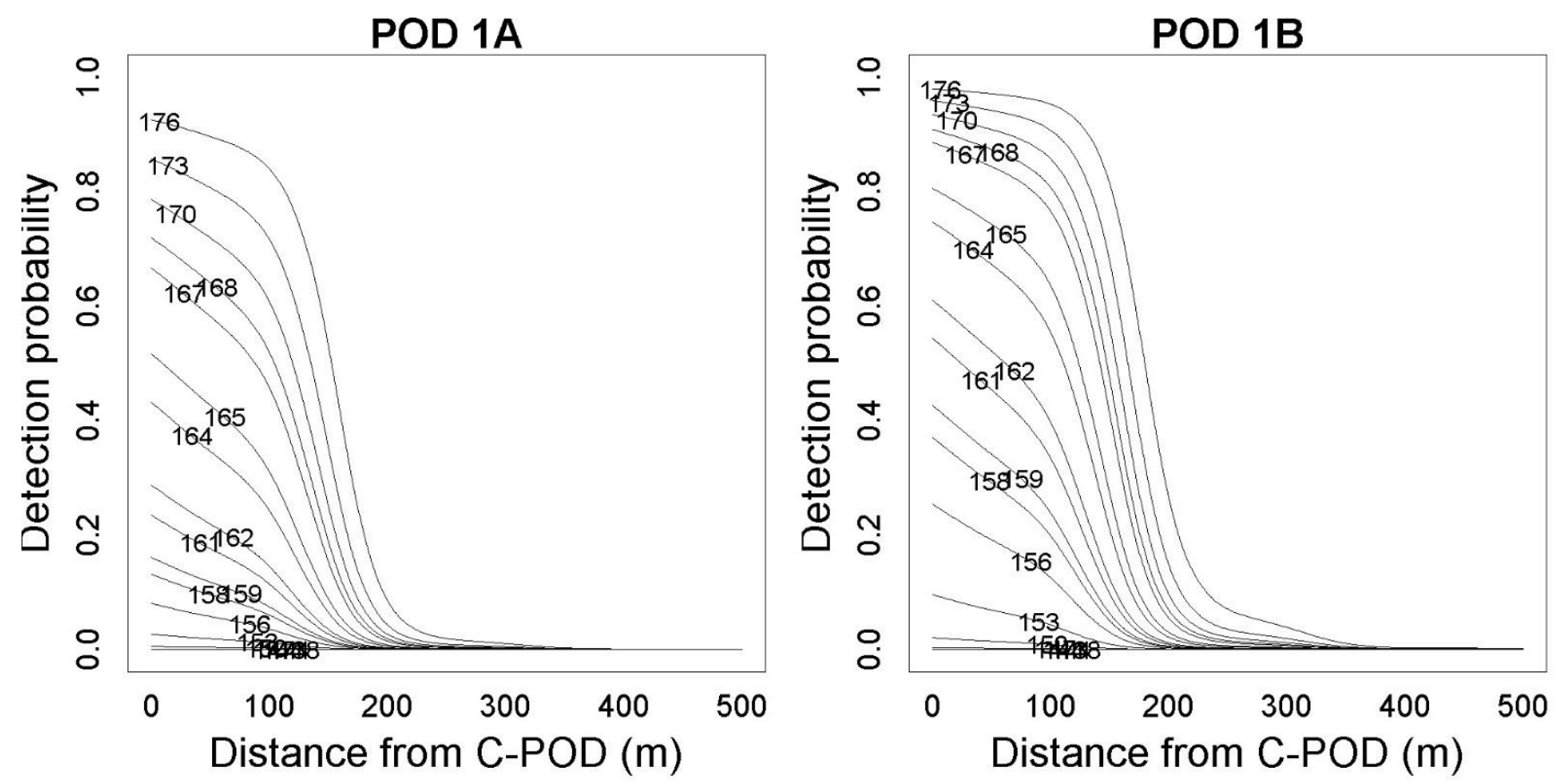

672 Figure 3. Fitted probability curves for the detection of artificial playback clicks at different

673 distances for source levels between 176 and $149 \mathrm{~dB}$ re $1 \mu \mathrm{Pa} / \mathrm{V} @ 1 \mathrm{~m}$ for C-PODs at stations

674 1A and 1B. Each line depicts the fitted probability for one $\mathrm{dB}$ value.

675

676

677

678

679

680 


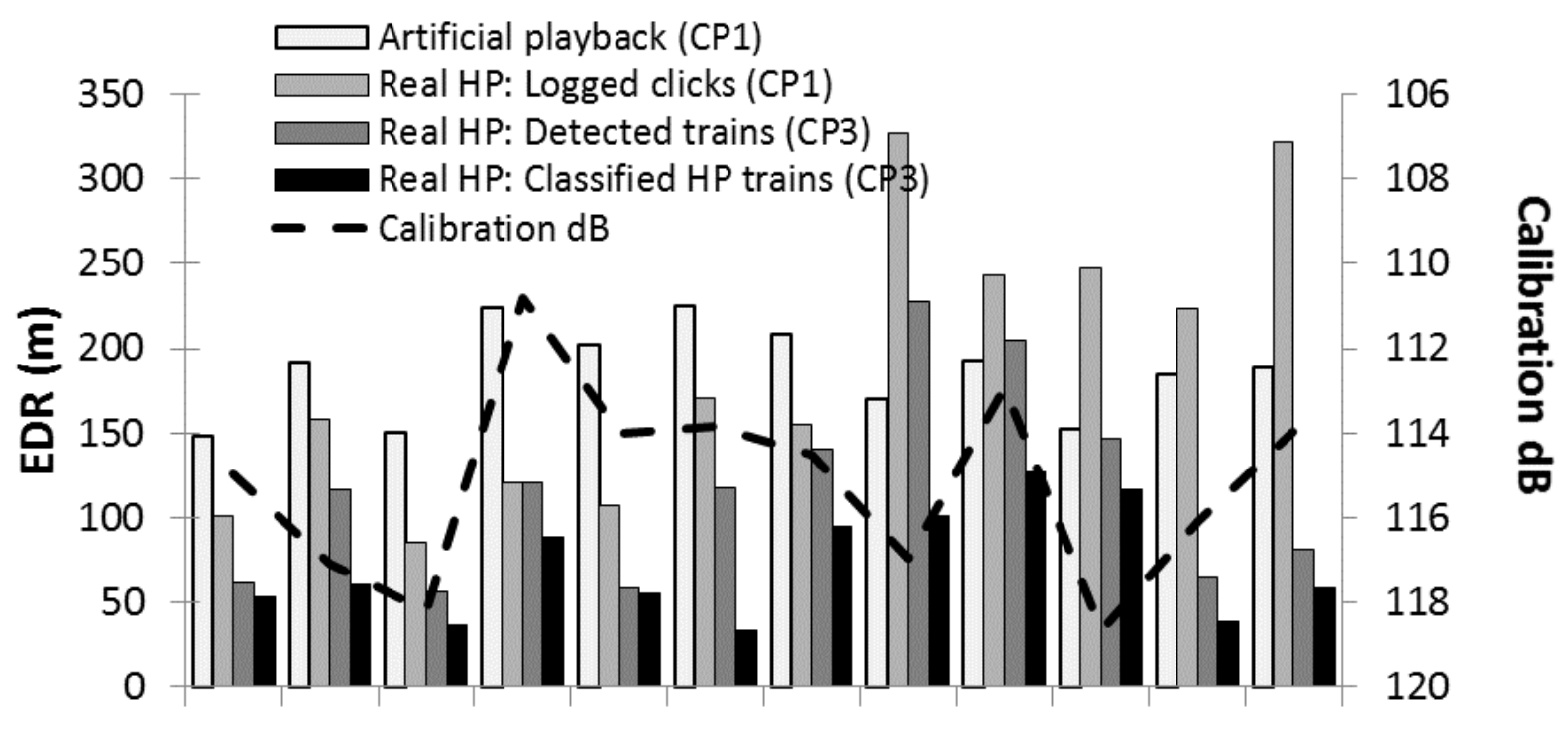

681

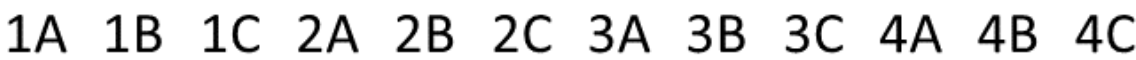

682 Figure 4. The effective detection radius (EDR) for both recorded porpoise sequence and the

683 artificial playbacks. Artificial playback of highest source level $176 \mathrm{~dB}$ (white), recorded porpoise

684 playback sequence for all logged clicks (light grey), all detected trains (dark grey) and all trains

685 classified as porpoise (black) on all C-PODs.

686 